УАк 657.1

\section{ГЕНЕЗИС СОЦІАЛЬНОГО АУАИТУ ${ }^{\odot}$}

ГОРДОПОЛОВА Н.В., кандидат економічних наук, доцент, торговельно-економічний коледжс КНТЕУ

(м. Kиїв),

СИСОЕВА І.М., кандидат економічних наук, доцент кафедри бухгалтерського обліку i аудиту, Вінницький навчально-науковий інститут економіки ТНЕУ,

ГОЛОВАЙ Н.М., кандидат економічних наук, доцент кафедри бухгалтерського обліку і аудиту, Вінницький навчально-науковий інститут економіки ТНЕУ (м. Вінниця)

Проаналізовано передумови виникнення соияіального аудиту, досліджено його основні параметри та наслідки впровадження в Украӥні.

Розглянуто соціальний аудит як специифічну форму аналізу, ревізії умов соціального середовища підприсмства з метою виявлення чинників соџіальних ризиків і вироблення пропозищій щзодо зниження їхнього впливу.

Досліджено еволючію сочіального аудиту в найбільш розвинутих крайнах світу. Розглянуто основні параметри соичільного аудиту.

Доведено, щуо соціальний аудит має можливість стати ефективним інструментом соиіального партнерства, щуо дозволяє здійснювати діалог між заџікавленими сторонами на основі достовірних результатів добровільного, незалежного $і$ об'єктивного аудиторського обстеження, щуо має на меті досягнення консенсусу в регулюванні соціоекономічних відносин.

Соиіальний аудит, навіть з урахуванням його подальшого вдосконалення, звичайно, не вирішить сучасних соціальних і екологічних бід. Однак його справедливо можна розглядати як своєрідну сочіальну інновацію, здатну з часом трансформуватися в дієвий механізм регулювання сочіально-економічних процесів в умовах глобалізації.

Ключові слова: соціальне середовище, соціальний аудит, чинники соціальних ризиків, параметри соціального аудиту, еволюція, менеджмент.

Табл.: 2. Літ.:12.

\title{
THE GENESIS OF SOCIAL AUDIT
}

GORDOPOLOVA Natalia, Candidate of Economic Sciences, Associate Professor, Trade and Economic College of the Kyiv National University of Trade and Economics

(Kyiv),

SYSOIEVA Inna, Candidate of Economic Sciences, Associate Professor of the Department of Accounting and Audit, Vinnytsia Educational and Scientific Institute of Economics of the Ternopil National Economic University, 
GOLOVAI Nadiya,

Candidate of Economic Sciences, Associate Professor of the Department of Accounting and Audit,

Vinnytsia Educational and Scientific Institute of Economics of the Ternopil National Economic University

(Vinnytsia)

The preconditions of the emergence of social audit are analyzed, its main parameters and implications of implementation in Ukraine are investigated.

The social audit is considered as a specific form of analysis, revision of the conditions of the social environment of the enterprise in order to identify the factors of social risks and to develop proposals to reduce their impact.

The evolution of social audit in the most developed countries of the world is explored. The basic parameters of social audit are considered.

It has been proved that social audit has the potential to become an effective tool of social partnership, which allows for dialogue between stakeholders on the basis of reliable results of a voluntary, independent and objective audit survey aimed at achieving consensus in the regulation of socioeconomic relations.

Social audit, even taking into account its further improvement, of course, will not solve modern social and environmental disasters. However, it can rightly be regarded as a kind of social innovation that can eventually transform into an effective mechanism for regulating socio-economic processes in a globalized world.

Key words: social environment, social audit, social risk factors, social audit parameters, evolution, management.

Tabl.: 2. Ref.: 12 .

\section{ГЕНЕЗИС СОЦИАЛЬНОГО АУДИТА}

ГОРДОПОЛОВА Наталья Васильевна, кандидат экономических наук, доцент, торгово-экономический колледж Киевского национального торгово-экономического университета (Киев),

СЫСОЕВА Инна Николаевна, кандидат экономических наук, доцент кафедры бухгалтерского учёта и аудита Винницкого учебно-научного института экономики Тернопольского национального экономического университета,

ГОЛОВАЙ Надежда Николаевна, кандидат экономических наук, доцент кафедры бухгалтерского учёта и аудита Винницкий учебно-исследовательский институт экономики Тернопольского национального экономического университета

(Винница)

Проанализированы предпосылки возникновения сочиального аудита, исследованы его основные параметры и последствия внедрения в Украине.

Рассмотрены сочиальный аудит как специфическую форму анализа, ревизии условий соииальной среды предприятия с иелью выявления факторов сочиальных рисков и выработка предложений по снижению их влияния

Исследована эволючия сочиального аудита в наиболее развитых странах мира. Рассмотрены основные параметры социального аудита.

Доказано, что социальный аудит имеет возможность стать эффективным инструментом сочиального партнерства, позволяет осуществлять диалог между заинтересованными сторонами на основе достоверных результатов добровольного, независимого и объективного аудиторского обследования, имеет иелью достижение консенсуса в регулировании соииоэкономических отношений. 
Сочиальный аудит, даже с учетом его дальнейтего совершенствования, конечно, не решит современных сочиальных и экологических бед. Однако его по праву можно рассматривать как своеобразную сочиальную инновачию, способную со временем трансформироваться в действенный механизм регулирования сочиально-экономических процессов в условиях глобализации.

Ключевые слова: социальная среда, социальный аудит, факторы социальных рисков, параметры социального аудита, эволюция, менеджмент.

Табл.:2. Лит.: 12.

Постановка проблеми. Поняття соціального аудиту прийшло до нас із закордонної практики. При цьому можна виокремити два основні джерела: науково-популярні статті, в яких основну увагу зосереджено на розкритті змісту та окремих проблемах соціального аудиту крізь призму його впровадження на рівні підприємства, галузі чи окремої території.

Ці статті мають переважно описовий характер і дають можливість накопичити та систематизувати теоретичну інформацію з цього питання; статті методичного спрямування, в яких авторами подано практичні рекомендації та пропозиції щодо проведення соціального аудиту на різних підприємствах. Статті є надзвичайно цінними для вітчизняної практики, оскільки дають як розуміння сутності соціального аудиту, так і конкретні вказівки та настанови на його проведення. Проте ми вважаємо, що кожен доробок науковців $з$ цієї тематики є надзвичайно важливим і дає можливість сформувати цілісне бачення сутності та значення соціального аудиту та скласти чітке уявлення про необхідні передумови здійснення соціального аудиту та його вплив на конкурентоспроможність вітчизняних підприємств.

Досліджуючи цю тему, ми побачили, що становлення та розвиток соціального аудиту - явище відносно нове не лише для України, але і для провідних країн світу. Через це єдиного цілісного визначення соціального аудиту немає. Переважно його розглядають як специфічну форму аналізу, ревізії умов соціального середовища підприємства з метою виявлення чинників соціальних ризиків і вироблення пропозицій щодо зниження їхнього впливу.

Аналіз останніх досліджень і публікацій. Питанням теорії, методології, організації і методики аудиту присвячено багато грунтовних досліджень провідних науковців України, зокрема Білухи М.Т., Бондаря В.П., Бондаря М.І., Бутинця Ф.Ф. [2, с. 10], Валуєва Б.І., Герасимовича А.М., Голова С.Ф., Гуцайлюка 3.В., Давидова Г.М., Дорош Н.I., Дрозд І.К., Завгороднього С.Я., Зубілевич С.Я., Івахненкова С.В., Калюги Є.В., Кіндрацької Л.М., Крупки Я.Д.[6, с.132], Кужельного М.В., Кузьмінського А.М., Максімової В.Ф., Малюги Н.М., Мниха Є.В., Петрик О.А. [9, с.15-16], Правдюк Н.Л., Пушкаря М.С., Редченка К.І., Редька О.Ю., Рудницького В.С., Савченка В.Я., Сопка В.В. [8, с. 8-9], Стефанюка І.Б., Сухаревої Л.О., Усача Б.Ф., Шевчука В.О. та ін.

Проте в теорії аудиту до сучасного моменту немає єдності думок, можна помітити лише певну спільність поглядів вчених, що базується на визнанні постулатів, принципів і категорій, які складають концепцію та концептуальні основи аудиту.

Незважаючи на значний внесок указаних вчених у розвиток теоретичних, методологічних, організаційних та методичних положень аудиту, зазначимо, що в сучасній економічній науці поки що відсутнє цілісне уявлення про особливості розвитку аудиту, його місце в системі соціальноекономічних відносин, що актуалізує необхідність дослідження еволюційних витоків, особливостей та інституційних детермінант його історичного розвитку.

Формулювання цілей статті. Отже, вибір теми та основні цілі статті зумовлені необхідністю чіткого визначення місця та функцій аудиту в сучасній системі соціальноекономічних відносин, визначення основних параметрів соціального аудиту та дослідження основних етапів розвитку та становлення аудиту в Україні, в умовах активізації інтеграційних процесів вітчизняної економіки до глобального економічного простору.

Виклад основного матеріалу дослідження. Контроль, як стверджують історичні джерела, має багатовіковий період розвитку. Це пов'язано з виникненням своєрідного обліку в державах, що були розташовані в долинах річок Ніл, Тигр та Свфрат. Спочатку облік вівся на папірусі, а вже пізніше на папері. У стародавньому Єгипті через кожні два роки проводилася інвентаризація рухомого та нерухомого майна. Вважається, що першою державою, в якій виникло спеціальне законодавство 3 ведення обліку був Вавилон. У стародавній Греції особлива увага надавалась контролю за збереженням власності, зокрема господарських засобів. В Афінах цією роботою займалися контролери, в обов'язки яких входило складання звітів про доходи і витрати держави, а в давньому Римі контроль повинен був попереджувати збитки, які виникали в результаті шахрайства, помилок та невміння вести господарство [1]. 
Отже, першими користувачами бухгалтерської інформації були рабовласники й феодали. Прагнучи, щоб управителі забезпечували отримання якнайвищого прибутку, власники, що їх наймали, призначали контролерів, які вислуховували звіти управителів. На державному рівні створювалися спеціальні органи, що контролювали збір податків та державні витрати. Цей вид контролю набув особливо швидкого розвитку після епохи Відродження в Свропі. На цьому етапі він вже відокремився від виконавчої влади і прийняв форму Урядового контролю за рахунками.

3 розвитком торгівлі та промисловості вирішальну роль у бюджеті країни стало відігравати надходження податків, а отже і податкова система. Для вирішення непорозумінь між податковими органами та управителями, які представляли інтереси власників, державного контролю вже було недостатньо, адже він захищав тільки інтереси держави. Тому виникла об'єктивна потреба в незалежному контролі, який дістав назву «аудит».

Батьківщиною виникнення аудиту вважається Великобританія, де починаючи з 1844 року виходить серія законів, згідно з якими правління компаній зобов'язане було запрошувати (як правило, один раз на рік) незалежного аудитора для перевірки бухгалтерських рахунків і звітів перед акціонерами. У 1862 році набуває чинності основний закон, що передбачав займатися аудиторською діяльністю - це Закон «Про британські компанії».

Також виникненню аудиту сприяв поділ інтересів між тими, хто вкладає грошові кошти в діяльність підприємства, і хто безпосередньо займається управлінням виробництвом. Аудиторській діяльності сприяло масове виникнення та активне функціонування акціонерних товариств, товариств 3 обмеженою відповідальністю та інших форм підприємництва на основі об'єднання капіталів декількох інвесторів.

У середині XIX століття, під час масового заснування акціонерних товариств, банків, страхових компаній, засновники спочатку цілком і повністю довіряли бухгалтерам і керівникам. Однак емісія цінних паперів, біржові спекуляції, створення фіктивних підприємств, $\mathrm{i}$, як логічний наслідок - масове банкрутство, призвели до недовіри до найманих працівників компаній.

Приблизно в цей же період аудит почав розвиватися і в інших найбільш розвинутих країнах, де швидко проходив процес концентрації та централізації виробництва і капіталу.

У зв’язку з цим у 1867 році у Франції було прийнято Закон про обов'язкову перевірку та оцінку Балансів підприємств і фірм незалежними аудиторами.

У США аудит виник після того, як в Північній Америці разом з англійськими страховиками та іншими інвесторами побували аудитори, які приїхали з метою захисту інтересів англійських кредиторів. Тому північноамериканський аудит має англійське походження.

У 1887 році в США була створена Асоціація аудиторів, а у 1896 році законодавчим органом штату Нью-Йорк був прийнятий закон, який регулював аудиторську діяльність і в подальшому став основою законів інших штатів.

Особливий поштовх в розвитку аудиторської справи дала світова економічна криза 19291933 років, коли масове банкрутство акціонерних товариств і підприємств інших форм власності вимагало більш суворого порядку перевірки їх звітності з боку незалежних аудиторів. У зв'язку $з$ цим у Німеччині в 1931 році було прийнято Урядову постанову, що передбачала обов'язкову аудиторську перевірку.

Також під впливом економічної кризи в США у 1934 році був прийнятий документ «Перевірка фінансових звітів незалежними аудиторами», в якому були рекомендовані такі процедури аудиту, як вивчення інвентарних відомостей та підтвердження дебіторської заборгованості.

У 1941 році в США з метою розвитку та вдосконалення професії внутрішнього аудитора був створений Інститут внутрішніх аудиторів.

На початку 70-х років XX сторіччя почалася розробка Міжнародних стандартів аудиту (MCA), які були видані Міжнародною федерацією бухгалтерів у 80-х роках. У східноєвропейських країнах (Польща, Угорщина, Румунія та інших) аудиторська діяльність почала розвиватися після розпаду Ради економічної взаємодопомоги (PEB). До цього вона вважалась недоцільною і не могла застосовуватися при командно-адміністративній системі господарювання.

На території України в складі царської Росії у 1911 році існував державний контроль в особі державного контролера, який входив до Ради Міністрів і губернаторських контрольних палат на місцях. У той час незалежна аудиторська діяльність не зазнала поширення.

У радянські часи в Україні функціонував лише державний контроль, який здійснювали Міністерство державного народного контролю УРСР, відомчі органи контролю, а згодом - Комітет народного контролю УРСР. 
У 1985 році, з початком перебудови в Радянському Союзі, з переходом до умов ринкових відносин і ринкового господарювання виникла об’єктивна необхідність розвитку аудиторської діяльності.

У 1987 році з появою в СРСР спільних підприємств іноземна сторона подала запит на аудиторське підтвердження фінансово-господарської діяльності спільних підприємств, що передувало прийняттю Радою Міністрів СРСР постанови про організацію в країні аудиторської діяльності.

Перша в СРСР аудиторська фірма «наудит» була створена в Москві 3 колишніх співробітників союзного Міністерства фінансів.

Згодом, коли іноземний капітал потрапив і до союзних республік, в Києві у 1989 році відкрилося дочірне відділення «Інаудит», яке було названо «Інаудит -Україна». Це була перша аудиторська фірма в Україні. До іï складу увійшли колишні держслужбовці системи республіканського Мінфіну УРСР, а також частково апарат Контрольно-ревізійного управління.

З 1992 по 1994 рік аналогічні аудиторські фірми були створені в Донецьку, Харкові, Львові, Тернополі та інших містах.

04 червня 1992 року в Києві була створена Спілка аудиторів України (САУ) як професійна громадська аудиторська організація. Вона стала ініціатором розробки проекту Закону України «Про аудиторську діяльність».

22 квітня 1993 року Верховною Радою України цей закон було затверджено і прийнято.

Відповідно до Закону України «Про аудиторську діяльність», у жовтні 1993 року була створена Аудиторська палата України (АПУ) як незалежний і самостійний орган, основна мета якої полягає у сприянні розвитку, вдосконаленню та уніфікації аудиторської діяльності в державі.

Пізніше на підставі клопотань територіальних відділень САУ, АПУ було створено 18 регіональних відділень, головним завданням яких є сприяння розвитку аудиту в регіонах, а також виконання та впровадження рішень АПУ.

Розпорядженням Кабінету Міністрів України 06 грудня 1993 року в складі Інституту підготовки спеціалістів був створений Національний центр обліку і аудиту, в завдання якого входить здійснення підготовки, перепідготовки та підвищення кваліфікації бухгалтерів і аудиторів, розробка та видання навчальних і методичних посібників з обліку, контролю, аналізу і аудиту.

16 травня 1994 року була створена Федерація керівників аудиторських фірм. Ї̈̈ основною метою $є$ підвищення ефективності роботи фірм, розробка та удосконалення методології аудиту, його теоретичних і практичних аспектів.

У 1998 році Аудиторська палата України разом із Спілкою аудиторів України розробила $\mathrm{i}$ прийняла Кодекс професійної етики аудиторів України (протокол №73 від 18.12.1998 року), який було введено в дію з 01 січня 1999 року.

Також АПУ, визначаючи відповідальність професії аудитора перед суспільством, і враховуючи те, що іiі роль полягає в забезпеченні кваліфікованих якісних аудиторських послуг, прийняла рішення запровадити Національні нормативи аудиту, які разом із Законом України «Про аудиторську діяльність» та Кодексом професійної етики аудиторів України регулюватимуть порядок проведення аудиторської діяльності на території держави. 301 січня 1999 року було введено обов'язковість дотримання 32 Національних нормативів аудиту, які діяли до 31 грудня 2003 року.

До червня 2000 року в Україні проводилося ліцензування аудиторів і аудиторських фірм, однак воно було тимчасово призупинено.

У жовтні 2000 року було введено Реєстрацію Суб’єктів аудиторської діяльності і видано «Положення про Реєстр Суб'єктів аудиторської діяльності», яке затверджено рішенням АПУ (протокол №95 від 31.10. 2000 року). Це Положення діє дотепер.

Черговий етап розвитку вітчизняного аудиту розпочався у 2003 році 3 прийняттям Аудиторською палатою України рішення про застосування Міжнародних стандартів аудиту як національних. Це зумовило перехід до принципово нової якості нормативного регулювання аудиторської діяльності.

Як правило, в організаціях використовується зовнішній аудит. Керівництво звертається до консалтингової фірми із запрошенням провести експертизу соціального характеру, наприклад, при впровадженні нової технології, перепрофілюванні виробництва, структурній реорганізації, створенні тимчасових чи оперативних творчих груп, вирішенні конфліктних ситуацій між працівниками і роботодавцем.

Соціальний аудит є багатовекторним поняттям, що дає відповіді на безліч запитань, вирішення яких сприятиме розвитку бізнесу, а відтак і соціально-економічному розвитку країни в цілому. Наразі важливо зародити усвідомлення того, що для сучасного бізнесу головною конкурентною перевагою стає наявність потужного людського капіталу, тому бізнес має орієнтуватися на підвищення вартості робочої сили. 
Постійне скорочення дії традиційних для України чинників набуття конкурентних переваг за рахунок отримання преференційних умов ведення бізнесу або використання дешевих матеріальних ресурсів має підвищувати зацікавленість українських компаній у конкуренції на основі моделі «дорогої» робочої сили, що передбачає гідну оплату праці. Така постановка питання повністю відповідає сучасній ідеології соціальної відповідальності бізнесу.

Досліджуючи цю проблематику, ми виявили необхідність наступного набору параметрів та індикаторів (табл. 1).

Тим часом подібні дослідження можуть служити прикладом ефективного використання фрагментів інформації для отримання лише часткової картини соціальної ситуації. Повна картина могла би бути отримана при впровадженні стандартизованих методик соціального аудиту, що передбачає: по-перше, розробку критеріїв оцінки ситуації на підприємстві, території, по-друге, розробку стандартів соціальної відповідальності як на підприємстві, так і на території.

Реалізація концепції соціального аудиту в довгостроковій перспективі дозволить оптимізувати процеси управління, прийняття управлінських рішень, як на мікро-, так і на макрорівнях.

Таблиия 1

Параметри соціального аудиту

\begin{tabular}{|c|c|c|}
\hline № 3/II & Параметри соціального аудиту & Характеристика \\
\hline 1 & 2 & 3 \\
\hline 1 & Демографічна ситуація & Щільність населення за регіонами, смертність \\
\hline 2 & Охорона здоров’я та безпека праці & Захворюваність населення за видами хвороб \\
\hline 3 & Освіта & $\begin{array}{l}\text { Чисельність осіб, які навчалися у навчальних закладах; } \\
\text { кількість загальноосвітніх навчальних закладів, } \\
\text { професійно-технічних навчальних закладів, вищих } \\
\text { навчальних закладів I-IV рівнів акредитації, показники } \\
\text { прийому студентів до ЗВО за джерелами фінансування } \\
\text { їхнього навчання, показники діяльності аспірантури та } \\
\text { докторантури; розподіл населення за рівнем освіти, за } \\
\text { статтю та місцем проживання }\end{array}$ \\
\hline 4 & Соціальна напруженість & $\begin{array}{l}\text { Заборгованість із виплати заробітної плати та окремих } \\
\text { видів соціальної допомоги, заборгованість населення з } \\
\text { оплати житлово-комунальних послуг, рівень } \\
\text { безробіття, чисельність працівників, які перебували у } \\
\text { відпустках } 3 \text { ініціативи адміністрації, кількість } \\
\text { страйків та їхні наслідки, порушення трудового } \\
\text { законодавства, коефіцієнти злочинності, чисельність } \\
\text { жебраків, кількість самогубств }\end{array}$ \\
\hline 5 & Зайнятість населення & $\begin{array}{l}\text { Економічна активність населення (за місцем } \\
\text { проживання, статтю, віковими групами), звільнення } \\
\text { працівників (за регіонами) }\end{array}$ \\
\hline 6 & Житлові умови & $\begin{array}{l}\text { Забезпеченість населення житлом, введення в } \\
\text { експлуатацію житлових будинків, кількість сімей та } \\
\text { одинаків, які перебували на квартирному обліку, } \\
\text { одержали житло та поліпшили свої житлові умови, } \\
\text { надання житла окремим категоріям населення }\end{array}$ \\
\hline 7 & Пенсійне забезпечення & $\begin{array}{l}\text { Види та розміри пенсій, чисельність пенсіонерів за } \\
\text { регіонами, середній розмір пенсій, співвідношення } \\
\text { середніх розмірів пенсії та заробітної плати } \\
\text { працівників, зайнятих в економіці }\end{array}$ \\
\hline 8 & $\begin{array}{l}\text { Соціально-демографічні } \\
\text { характеристики домогосподарств }\end{array}$ & $\begin{array}{l}\text { Розмір, склад, житлові умови, наявність і } \\
\text { використання земельних ділянок, характеристика } \\
\text { особистих підсобних господарств, рівень освіти } \\
\text { населення, рівень розвитку фізкультури та спорту, } \\
\text { структура доходів та витрат }\end{array}$ \\
\hline 9 & Заробітна плата & $\begin{array}{l}\text { Середньомісячна номінальна заробітна плата } \\
\text { працівників (за галузя-ми економіки, регіонами, } \\
\text { видами діяльності), структура фонду оплати праці, } \\
\text { індекси заробітної плати та інфляції, галузеві }\end{array}$ \\
\hline
\end{tabular}


Продовження табл. 1

\begin{tabular}{|c|l|l|}
\hline 1 & \multicolumn{1}{|c|}{2} & \multicolumn{1}{|c|}{3} \\
\hline & \multicolumn{1}{|c|}{} \\
\hline 10 & Бідність & $\begin{array}{l}\text { співвідношення заробітної плати, співвідношення } \\
\text { заробітної плати та прожитко вого мінімуму для } \\
\text { працездатної особи }\end{array}$ \\
\hline 13 & $\begin{array}{l}\text { Соціально-економічна захищеність } \\
\text { населення }\end{array}$ & $\begin{array}{l}\text { Порівняльний аналіз бідності в Україні та в інших } \\
\text { країнах } \\
\text { Базова захищеність, захищеність доходів, професійних } \\
\text { умінь безпека ринку праці, умов праці, гарантії } \\
\text { зайнятості та волевиялення, соціальна справедливість }\end{array}$ \\
\hline $\begin{array}{l}\text { Стан дотримання Кодексу законів } \\
\text { про працю України на підприємствах } \\
\text { різних форм власності }\end{array}$ & $\begin{array}{l}\text { Струкура порушень трудового законодавства: оплату } \\
\text { праці, гарантії та компенсації, укладення і виконання } \\
\text { колективних договорів, трудові відносини у разі } \\
\text { банкрутства, працю жінок, молоді, інвалідів }\end{array}$ \\
\hline
\end{tabular}

Джерело: сформовано авторами на основі літературних джерел

Зарубіжний соціальний аудит спирається значною мірою на правові норми, зафіксовані в ряді універсальних міжнародних договорів: Статут ООН (1945), Загальна декларація прав людини (1948), Міжнародний пакт про економічні, соціальні і культурні права (1966), Заключний акт Наради але безпеки і співробітництва в Свропі (1975) та ін. (табл. 2).

Таблиия 2

Зарубіжний досвід соціального аудиту

\begin{tabular}{|c|c|c|}
\hline Країна & $\begin{array}{c}\text { Особливості еволюції соціального } \\
\text { аудиту в країні }\end{array}$ & Сучасний етап соціального аудиту \\
\hline 1 & 2 & 3 \\
\hline Франція & 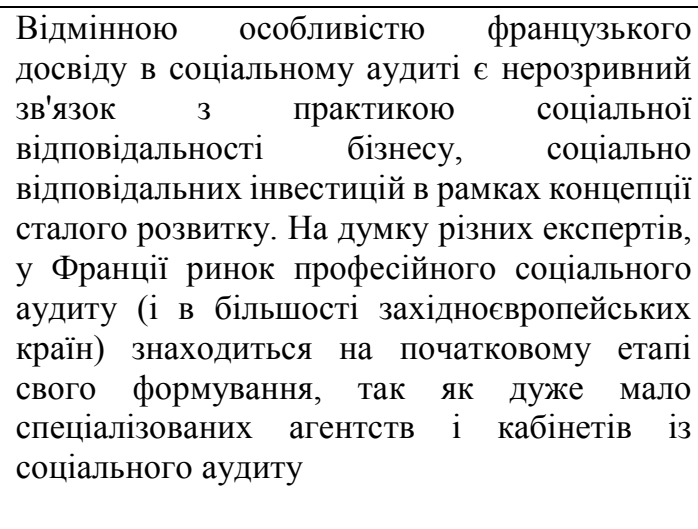 & $\begin{array}{l}\text { Хоча соціальний аудит Франції в цей час } \\
\text { набув популярності і дуже затребуваний, } \\
\text { проте фірми соціального аудиту } \\
\text { залишаються невеликими порівняно } 3 \\
\text { агентствами фінансового моніторингу. На } \\
\text { практиці це пояснюється тим, що } \\
\text { підприємствам, які бажають отримати } \\
\text { доступ до фінансових ринків, необхідно в } \\
\text { обов'язковому порядку отримати } \\
\text { відповідну оцінку їнього фінансового } \\
\text { рейтингу. Відомими агентствами із } \\
\text { соціального аудиту є: французьке Vigeo, } \\
\text { американське Innovest і швейцарське SAM }\end{array}$ \\
\hline США & $\begin{array}{l}\text { Американська система управління на рівні } \\
\text { господарчих суб'єктів має особливе } \\
\text { значення, оскільки менеджмент як наука і } \\
\text { мистецтво зародився там на початку ХХ ст. } \\
\text { Історична еволюція соціального аудиту в в } \\
\text { США свідчить про різноманіття його форм і } \\
\text { певної закономірності іх розвитку. } \\
\text { Аудиторський обстеження починалося } 3 \\
\text { найбільш простої його форми - соціального } \\
\text { рейтингу. Потім відбувся перехід до } \\
\text { соціальної звітності. Ще пізніше соціальна } \\
\text { звітність стала спиратися на соціальні } \\
\text { стандарти. При всьому різноманітті форм } \\
\text { соціального аудиту він, тим не менше, } \\
\text { зумовлений зростанням корпоративної } \\
\text { соціальної відповідальності }\end{array}$ & $\begin{array}{l}\text { Основною особливістю американської } \\
\text { моделі соціальної відповідальності є } \\
\text { слабке державне регулювання цієї сфери. } \\
\text { Уряд, зацікавлений в посиленні системи } \\
\text { соціального забезпечення, перекладає } \\
\text { вирішення частини соціальних проблем на } \\
\text { місцевий рівень, на некомерційний сектор } \\
\text { i бізнес. Місцева влада, позбувшись } \\
\text { підтримки на державному рівні, змушена } \\
\text { шукати союз з бізнесом для вирішення } \\
\text { соціальних проблем, тому соціально- } \\
\text { відповідальної поведінки компаній } \\
\text { сприймаєтся в США практично як } \\
\text { категоричний імператив }\end{array}$ \\
\hline Німеччина & $\begin{array}{l}\text { Становлення німецької моделі соціального } \\
\text { аудиту співпало з розвитком теорії соціальної } \\
\text { держави, відповідно до якої Німеччина повинна } \\
\text { стати демократичною і соціальною федеративною }\end{array}$ & $\begin{array}{l}\text { Розвиток соціального аудиту в Німеччині } \\
\text { за останні роки демонструє зростання } \\
\text { зацікавленості до його проведення як } 3 \\
\text { боку роботодавців, так і працівників. }\end{array}$ \\
\hline
\end{tabular}




\section{http://efm.vsau.org/}

Продовження табл. 2

\begin{tabular}{|c|c|c|}
\hline 1 & 2 & 3 \\
\hline & 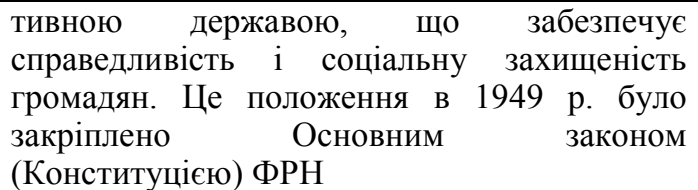 & $\begin{array}{l}\text { Більше того, він всіляко підтримується } \\
\text { державною владою }\end{array}$ \\
\hline
\end{tabular}

Джерело: сформовано авторами на основі літературних джерел

Сучасний розвиток соціального аудиту зумовлений двома групами факторів. Перша 3 них визначається прагненням використовувати соціальний аудит 3 метою отримання економічної вигоди. Ця особливість надає американській моделі соціального аудиту суто прагматичного характеру. Практика також показала, що соціальний аудит - це інструмент, який допомагає менеджерам краще зрозуміти і прогнозувати потреби стейкхолдерів. Цей інструмент забезпечує істотну інформацію про інтереси, потреби та очікування стейкхолдерів, полегшуючи взаємозалежність, яка існує між бізнесом і його стейкхолдерами, заохочуючи взаємність, тобто забезпечує двосторонній розвиток.

Соціальний аудит здатний надати велику ефективність менеджменту. Він інтегрується 3 чинними системами управління, і завдяки цьому менеджери, відповідальні за щоденне прийняття рішень, можуть більш ефективно використовувати інновації і реінжиніринг.

Соціальний аудит використовується як технологія контролю стратегічних цілей компанії. У процесі соціального аудиту стратегія компанії стає більш свідомою і виявляються неузгодженості тактики і стратегії.

Друга група чинників пов'язана із суспільним тиском на корпорації. Суспільство зацікавлене в підвищенні прозорості діяльності корпорації. Соціальний аудит, зроблений добровільно або в результаті зовнішнього замовлення, передбачає більш високий рівень точності оцінок та інформації, одержаних у процесі аудиту.

Крім того, соціальний аудит має можливість стати ефективним інструментом соціального партнерства, що дозволяє здійснювати діалог між зацікавленими сторонами на основі достовірних результатів добровільного, незалежного й об'єктивного аудиторського обстеження, що має на меті досягнення консенсусу в регулюванні соціоекономічних відносин.

Висновки. Отже, соціальний аудит здатний надати соціальним партнерам на підприємстві, органам влади, професійним об'єднанням об’єктивну інформацію, сформовану в результаті обстеження реального стану справ на підприємстві. Ця інформація буде сприяти соціальному діалогу і допоможе відповідальним особам прийняти більш виважене рішення, контролювати його реалізацію, передбачити можливі труднощі, вчасно вжити необхідних заходів для їх вирішення. Соціальний аудит, який виконується за міжнародними стандартами, формує впевненість, що компанія працює добре; його результати дозволять побачити недоліки та скоригувати діяльність компанії, а це сприятиме досягненню більшого економічного ефекту.

Хоча, як будь-яке нововведення, соціальний аудит не отримує однозначної оцінки. Однак, не викликає сумніву той факт, що усі соціально-економічні чинники створюють необхідність нового мислення, заснованого на ідеї сталого розвитку, найважливішим компонентом якого $є$ «соціальний вимір». Звичайно, соціальний аудит, навіть з урахуванням його подальшого вдосконалення, не вирішить сучасних соціальних і екологічних проблем. Однак, його справедливо можна розглядати як своєрідну соціальну інновацію, здатну з часом трансформуватися в дієвий механізм регулювання соціально-економічних процесів в умовах глобалізації.

\section{Список використаних джерел}

1. Бойцова В.А. Социальная ответственность бизнеса: обязанность или необходимость? [Електронний ресурс] / В. А. Бойцова // Концепт. 2015. № 14. - Режим доступу: http://ekoncept.ru/2015/75203.htm.

2. Бутинець Ф.Ф. Аудит: Підручник для студентів спеціальності “Облік і аудит» вищих навчальних закладів. 2-ге вид., перероб. і доп. / Франц Францович Бутинець. 2-ге вид., перероб. та доп. Житомир: ПП «Рута», 2002. 672 с.

3. Ирназаров Р. И. Социальная ответственность: к вопросу о возникновении / Р. И. Ирназаров, М. Х. Юсупова // Вестник Башкирского университета. 2011. Т. 16 Философия, социология, культурология и политология. № 1. С. 176-180.

4. Калетнік Г.M. Efficiency of state support as the basis of sustainable agriculture / Г.М. Калетнік, Н.В. Пришляк. // Економіка. Фінанси. Менеджмент: актуальні питання науки і практики. 2016. №5. С. 7-23. 


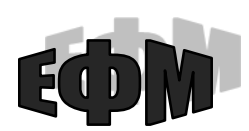

http://efm.vsau.org/

5. Колот А.М. Соціально-трудова сфера: стан відносин, нові виклики, тенденції розвитку: [моногр.] / Колот А. М. Київ: КНЕУ, 2010. 215 с.

6. Крупка Я.Д. Користувачі облікової інформації та проблеми задоволення їх інформаційних потреб / Ярослав Дмитрович Крупка // Вісник ЖДТУ. Економічні науки. 2010. № 3. С. 132-134.

7.Мельник С.В. Концепція формування національної моделі соціального аудиту [Електронний ресурс] / Мельник С.В., Матросов В.Д., Гаврицька М.К. Режим доступу : http://www.lir.lg.ua/koncep.htm.

8. Організація і методика проведення аудиту: Навч.-практ. посібник / В. В. Сопко, В.П. Шило, Н.І. Верхоглядова та ін. 2-ге вид., перероб. та доп. Київ: ВД «Професіонал», 2006. 576 с.

9. Петрик О.А. Аудит у зарубіжних країнах: Навч. метод. посібник для самост. вивч. дисц. / О.А. Петрик, М.Т. Фенченко / За заг. ред. О.А. Петрик. Київ: КНЕУ, 2002. 168 с.

10.Сисоєва І. Особливості аудиту облікової політики підприємств / І. Сисоєва // Галицький економічний вісник. 2007. Вип. 4 (15). С. 188-192.

11. Sysoieva I. Modelling of enterprise's accounting policy: theoretical aspect / Sysoieva I., Balaziuk O., Pylypenko L.// Baltic Journal of Economic Studies, Volume 5 Number 1. Riga: Publishing House «Baltija Publishing», 2019, 256 p. P. 188-194. DOI: https://doi.org/10.30525/2256-0742/2019-5-1-188-193.

12.Туркин С. Социальный аудит компаний [Электронный ресурс] / С. Туркин // Управление компанией. 2004. № 8. Режим доступа: http://www.cfin.ru/press/zhuk/2004 -8/15.shtml.

\section{References}

1. Boytsova V.A. (2015). Sotsialnaya otvetstvennost biznesa: obyazannost ili neobhodimost? [Business Social Responsibility: Duty or Necessity?]. Kontsept - Concept, No.14. Available at: http://ekoncept.ru/2015/75203.htm [in Ukrainian].

2. Butynets, F. F. (2002). Audyt [Audit]. Zhytomyr, Ruta, 672.

3. Irnazarov R.I., Yusupova M.H. (2011). Sotsialnaya otvetstvennost: k voprosu o vizniknovenii [Social responsibility: to the question of emergence].Vestnik Bashkirskogo universiteta. Filosofiya, sotsiologiya, kulturologiya i politologiya - Bulletin of the Bashkir University. Philosophy, Sociology, Cultural Studies and Political Science, Vol. 16, pp. 176-180 [in Russian].

4. Kaletnik, H.M., Pryshliak, N.V. (2016). Efficiency of state support as the basis of sustainable agriculture [Efficiency of state support as the basis of sustainable agriculture]. Ekonomika. Finansy. Menedzhment: aktual'ni pytannia nauky i praktyky - Economy. Finances. Management: actual issues of science and practical activity, 5, 7-23 [in Ukrainian].

5. Kolot A.M. Sotsial'no-trudova sfera: stan vidnosyn, novi vyklyky, tendentsiyi rozvytku [Social and labor sphere: the state of relations, new challenges, tendencies of development]. Kyiv, KNEU, 215 p. [in Ukrainian].

6. Krupka, Ya.D. (2010). "Korystuvachi oblikovoi informatsii ta problemy zadovolennia ikh informatsiinykh potreb" [Users of accounting information and problems meeting their information needs]. Visnyk ZhDTU. Ekonomichni nauky - Bulletin of ZhSTU. Economic sciences, No. 3, pp. 132-134 [in Ukrainian].

7. Mel'nyk S.V. Kontseptsiya formuvannia natsyonal'noi modeli SOTSIAL'NOHO audytu [The Concept of Formation of National Model of Social Audit]. Available at: http://www.lir.lg.ua /koncep.htm [in Ukrainian].

8. Sopko, V.V., Shylo, V.P., Verkhohliadova, N.I. (2006). Orhanizatsiia i metodyka provedennia audytu [Organization and methodology of the audit]. Kyiv, Profesional, 576 [in Ukrainian].

9. Petryk, O.A., and Fenchenko, M.T. (2002). Audyt u zarubizhnykh krainakh [Audit in foreign countries]. Kyiv, KNEU, 168 [in Ukrainian].

10.Sysoieva I. Osoblyvosti audytu oblikovoyi polityky pidpryyemstv (2007). [Features of audit of accounting policy of enterprises]. Halyts'kyy ekonomichnyy visnyk - Galician Economic Bulletin, Issue 4(15), pp. 188-19 [in Ukrainian].

11. Sysoieva I. (2019). Modelling of enterprise's accounting policy: theoretical aspect. Baltic Journal of Economic Studies, Vol. 5, No. 1. Riga, Publishing House «Baltija Publishing», 256 p, pp. 188-194.

12.Turkin S. (2004). Sotsial'nyy audyt kompaniy [Social audit of companies]. Upravleniye kompaniyey - Management of the company, No. 8. Available at: http://www.cfin.ru/press/zhuk/2004 8/15.shtml [ in Russian].

\section{Інформація про авторів}

ГОРДОПОЛОВА Наталія Василівна - кандидат економічних наук, доцент, торговельноекономічний коледж Київського національного торговельно-економічного університету (03115, м. Київ, вул. Львівська, 2/4, natgordopol@ukr.net).

СИСОЄВА Інна Миколаӥвна - кандидат економічних наук, доцент кафедри бухгалтерського обліку i аудиту Вінницький навчально-науковий інститут економіки Тернопільського національного економічного університету (21017, м. Вінниця, вул. Гонти, 37, еmail:innas1853@gmail.com). 


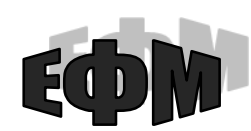

http://efm.vsau.org/

ГОЛОВАЙ Надія Миколаївна - кандидат економічних наук, доцент кафедри бухгалтерського обліку i аудиту, Вінницький навчально-науковий інститут економіки Тернопільського національного економічного університету (21017, м. Вінниця, вул. Гонти, 37, еmail: nadyagolovay@gmail.com).

GORDOPOLOVA Natalia - Candidate of Economic Sciences, Associate Professor, Trade and Economic College of the Kiev National University of Trade and Economics (03115, Kyiv, 2/4 Lviv Str., natgordopol@ukr.net).

SYSOIEVA Inna - Candidate of Economic Sciences, Associate Professor of the Department of Accounting and Audit, Vinnytsia Educational and Scientific Institute of Economics, Ternopil National Economic University (21017, 37 Gonty Str., Vinnytsia, e-mail: innas1853@gmail.com).

GOLOVAI Nadezhda - Candidate of Economic Sciences, Associate Professor of the Department of Accounting and Audit, Vinnytsia Educational and Scientific Institute of Economics of Ternopil National Economic University (21017, 37 Gonty Str., Vinnytsia, e-mail: nadyagolovay@gmail.com).

ГОРДОПОЛОВА Наталья Васильевна - кандидат экономических наук, доцент, Торговоэкономический колледж Киевского национального торгово-экономического университета (03115 г. Киев, ул. Львовская, 2/4, natgordopol@ukr.net).

СЫСОЕВА Инна Николаевна - кандидат экономических наук, доцент кафедры бухгалтерского учёта и аудита, Винницкий учебно-научный институт экономики Тернопольского национального экономического университета (21017, г. Винница, ул. Гонты, 37, e-mail: innas1853@gmail.com).

ГОЛОВАЙ Надежда Николаевна - кандидат экономических наук, доцент кафедры бухгалтерского учёта и аудита, Винницкий учебно-научный институт экономики Тернопольского национального экономического университета (21017, г. Винница, ул. Гонты, 37, e-mail: nadyagolovay@gmail.com).

\begin{tabular}{|c|c|}
\hline УАК 336.226 .657 & \\
\hline $\begin{array}{l}\text { ЕКОЛОГІЧНИЙ ПОДАТОК: ПОРЯДОК } \\
\text { ОПОААТКУВАННЯ ТА ВІДОБРАЖЕННЯ В } \\
\text { СИСТЕМІ БУХГАЛТЕРСЬКОГО ОБЛІКУ }\end{array}$ & $\begin{array}{r}\text { ПЛАХТІЙ Т.Ф., } \\
\text { доктор економічних наук, доцент, } \\
\text { доцент кафедри обліку та оподаткування } \\
\text { в галузях економіки, } \\
\text { Віннццький національний } \\
\text { аграрний університет, } \\
\text { ДРАЧУК В.Ю., } \\
\text { викладач кафедри обліку і оподаткування, } \\
\text { Вінницький фінансов- } \\
\text { економічний університет } \\
\text { (м. Вінниця) }\end{array}$ \\
\hline
\end{tabular}

Стаття присвячена актуальним питанням оподаткування екологічним податком та відображенням в системі бухгалтерського обліку. Авторами проведено дослідження сучасного стану оподаткування в розрізі елементів екологічного податку та проаналізовано обсяги надходжень такого виду податкового платежу до бюджету за видами забруднень навколишнього природного середовища. Розкрито важелі впливу на рівні начіонального, регіонального та місиевого управління, які дозволяють реалізувати природоохоронні програми та заходи в правовому полі. Удосконалено документальне відображення операцій з нарахування зобов'язань за екологічним податком, зважаючи на сучасні вимоги користувачів облікової інформачії. Результати представлено у вигляді допоміжних відомостей в розрізі видів забруднень навколишнього природного середовища. Розроблено систему аналітичних рахунків щуодо проведення розрахункових операчій з бюджетом за екологічним податком та представлено їх практичне застосування. 